\title{
Risk Analysis of Chemical Hazards Based on the Case of EU Children's Products Recalled and Study on the Reasonable Limitation of Harmful Element in Toys
}

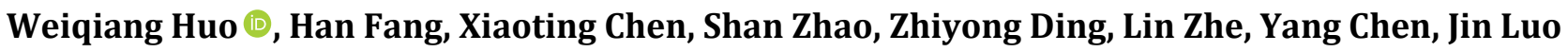 \\ Guangzhou Customs District Technology Center, Guangzhou, China
}

Correspondence to: Weiqiang Huo, huowq@iqtcnet.cn

Keywords: Products for Children, Chemical Hazard Risk Factors, Limitation of Boron

Received: November 30, $2021 \quad$ Accepted: January 3, $2022 \quad$ Published: January 6, 2022

Copyright $\odot 2022$ by author(s) and Scientific Research Publishing Inc.

This work is licensed under the Creative Commons Attribution International License (CC BY 4.0).

http://creativecommons.org/licenses/by/4.0/

\section{(c) (1) Open Access}

\section{ABSTRACT}

The trade situation about China's export of toy products to the EU was introduced. The recall characteristics of China's toy products by the EU "Safety Gate" in terms of recall frequency, notified countries, taken measures, and reasons for recall were analyzed in this paper, and the risk factors of human health of unqualified products in terms of chemical hazards were studied in this paper. It is found that phthalate, boron, plumbum and cadmium were the main factors. Assessment of risk for boron in toys was conducted. It is suggested to limit the boron element in Slime: the limit of migration of boron in Slime toys for 3- to 6-year-old children shall be less than $704 \mathrm{mg} / \mathrm{kg}$, and the limitation of migration of boron in Slime toys for 7- to 12 -year-old children shall be less than $1268 \mathrm{mg} / \mathrm{kg}$.

\section{INTRODUCTION}

Impacted by the Brexit, the escalation of the trade dispute between the United States and China and the Covid-19 pandemic, global trade in toys has suffered enormously. However, benefiting from a boost to exports from emerging markets and countries along the Belt and Road Initiative, China is seeing strong growth in the export trade of toys. As the concern for the safety, health and environmental protection of toys has become prominent worldwide, the European Commission has frequently introduced Technical Barriers to Trade (TBT) related to toys to warn, withdraw, recall and detain noncompliant products. With the analysis of the EU recall of China's toy products and chemical risk factors, this paper was studied for the reasonable threshold of the harmful element boron so as to provide a practical reference for the high-quality development of the toy industry, which delivers positive significance to the export trade of toy products.

\section{THE EXPORT OF CHINA'S TOY TRADE TO EUROPE}

Affected by increasing global trade frictions and factors such as Brexit, China's toy products exported 
to the EU trade in 2018 fluctuated sharply and the growth rate fell back. The total export trade amounted to $\$ 5.679$ billion, accounting for $22.66 \%$ of the total global trade in toy products exports. Thanks to favorable factors such as the economic recovery of the EU and the increase in per capita disposable income of residents, as well as purchasers ordering earlier shipments for fear of increased economic frictions and some enterprises shifting to the EU market with outstanding consumption power after the turmoil in the U.S. market, the total export trade of China's toy products in 2019 amounted to $\$ 7.729$ billion, representing a year-on-year increase of $36.08 \%$. However, affected by Covid-19, the total export trade of China's toy products fell to $\$ 5.67$ billion in 2020 . The Covid-19 is still rampant in several major EU countries and will continue to have a profound impact on China's toy exports to Europe [1].

\section{ANALYSIS OF THE RECALL OF TOY PRODUCTS IN CHINA BY EU SAFETY GATE}

\subsection{Recall Frequency}

According to the data notified by the EU "Safety Gate" statistics, from 2011 to 2020, the EU "Safety Gate" recalled (detained) a total of 22,120 batches of foreign consumer goods, which accounted for $55.47 \%$ of the total of 12,271 batches of China's consumer goods recalled (detained). Of which, the most recalled (detained) is toys, with a total of 5793 batches, accounting for $26.19 \%$. It can be revealed through the 2011-2020 EU “Safety Gate" recalls (detained) batches of China's toy products, the EU "Safety Gate" recalls show a fluctuating oscillating flattening trend. In the past three years, in the case that the volume of export trade of China's toy products is slightly reduced, the number of recalls notified and the number of follow-up actions by member states tends to slowly decline [2].

\subsection{Reasons for Recall}

The main reasons for the recall of China's toy products in the EU in 2020 mainly concerns three aspects of chemical safety, mechanical and physical safety, and combustion safety [2] Multiple risk factors are likely to exist in the same product, for example, in electric toys, the battery is a small part, which may lead to damage to the gastrointestinal tract of children if placed in the mouth and swallowed, and may also cause choking and suffocation and other mechanical and physical hazards [3]. Damaged or leaking batteries can pose chemical hazards due to chemical leaks; plastic parts such as battery covers may exceed the standard for phthalate and other chemical hazards [4]. Soldering materials may contain plumbum, cadmium, etc., causing heavy metal chemical hazards. Batteries may also cause continuous burn hazards to children due to overheating [5]. In addition, polyimide film packaging electric toys was too thin, which easily caused choking hazards if covered on the children's mouth and nose [6].

\section{ANALYSIS OF CHEMICAL HAZARD RISK FACTORS}

In 2020, European Union recalled toys products of China for 236 times because of chemical security, mainly including: overproof phthalate, and other organic poisonous substances like boron, plumbum, cadmium, and so on.

\subsection{Phthalate}

The batches recalled due to overproof phthalate are the largest in number-117 batches, accounting for $49.57 \%$ of overall batches. The value of phthalate in plastic component of plastic toys and stuffed toys like DEHP, DBP, DINP and DIBP severely exceeds the limit, which may be detrimental to the genital system of infants and children, violating REACH Regulation, instruction of toy safety and the regulations of EU's standard EN 71-1. These years, the limitation of EU towards phthalate becomes more and more strict. In the end of 2018, EU issued (EU) 2018/2005 regulation, expanding the limit number from three to four (DIBP was added), more strictly restricting to less than $0.1 \%$, and extending its control scope. 


\subsection{Boron (B)}

The boron in the likes of slime severely exceeds the limit. 74 batches were recalled (detained), covering $31.36 \%$ of total batches. Excess Boron may harm the genital system and endocrine system of children, which violates toy security instruction and the regulation of EU's EN71-3. EN71-3 stipulates that the migration limit value of Boron in liquid or viscous toys is $300 \mathrm{mg} / \mathrm{kg}$. According to the data in "Safety Gate" notification, the measured Boron in recalled slime toys of China severely exceeds the limit, which is 1497 $\mathrm{mg} / \mathrm{kg}$ on average and is about 5 times of that of EU. One of the measured Boron migration value is as high as $6960 \mathrm{mg} / \mathrm{kg}[2]$.

\subsection{Plumbum $(\mathrm{Pb})$ and Cadmium $(\mathrm{Cd})$}

The environmental hazard substance like plumbum and cadmium in welding materials of some electronic toys exceeds the limit. Plumbum and cadmium may pose risks to the environment and violate the requirements of RoHS 2.0 instruction. A total of 80 batches were recalled/detained, accounting for $33.90 \%$ of the total recalled (detained) batches. The RoHS 2.0 instruction stipulates that the maximum permissible content of plumbum $(\mathrm{Pb})$ and cadmium $(\mathrm{Cd})$ is $0.1 \%(1000 \mathrm{ppm})$ and $0.01 \%(100 \mathrm{ppm})$ respectively. According to the data in "Safety Gate" notification, plumbum and cadmium in the recalled electronic toys of China severely exceed the limit with the average measured value of plumbum as high as $63.75 \%$, which is 637 times of RoHS2.0 permissible limit of plumbum [2].

\section{REASONABLE LIMITATION STUDY OF BORON IN TOYS}

Owing to the severe safe risk of boron in Slime, ISO/TC181 has launched the study of boron limit setting in Slime in the first half year of 2020, and prepared to make relevant modification to ISO 8124-3. EU has already regulated the limit of Boron. As the biggest producer and exporter of toys, China has not limited the boron content of relevant materials in GB6675.4, leading to the lack of supervision basis for China's import and export of relevant toys, which is not conducive to supervising hazards of toys. The limits of boron in Slime are set to provide technical basis for market supervision and port supervision and regularity enforcement according to EU RIVM report 320003001/2008 General Method for Safety Evaluation of Chemicals in Toys (hereinafter referred to as "RIVM Report") [7] and Manual of Exposure Parameters for Chinese People (Children's Volume) [8].

\subsection{Daily Exposure Dose}

Children are prone to get boron through mouth when playing with Slime. In addition, the EU RIVM Report sets product age bracket of viscous material (the classification of Slime in EU's standard) as under the age of [7]. However, based on researches for domestic main manufacturers, the domestic Slime is mainly provided to children aged over 3, which should be set as the age bracket of this product.

In line with RIVM report and Manual of Exposure Parameters for Chinese People (Children's Volume) $[7,8]$, for toy products that can be put into the mouth for the children over the age of 3 , the daily exposure dose is shown in Table 1.

\subsection{Limit Setting}

1) Limit calculation formula

EU RIVM Report 320003001/2008 General Method for Safety Evaluation of Chemicals in Toys uses

Table 1. Daily exposure dose of toy products for children aged over 3.

\begin{tabular}{cc} 
Material type & All toy materials \\
\hline Oral and/or dermal exposure resulting in daily exposure dose/mg/day & 400 \\
\hline
\end{tabular}


Table 2. Allowable risk limit setting of boron in Slime products.

\begin{tabular}{cc}
\hline Applicable age of product & Limitation of allowable risk $(\mathrm{mg} / \mathrm{kg})$ \\
\hline $3-6$ years old & 704 \\
$7-12$ years old & 1268 \\
\hline
\end{tabular}

the following formula when calculating the limits of chemicals [7]:

$$
10 \% \text { TDI } \times \text { child's weight }(\mathrm{kg}) / \text { daily exposure dose = elemental limit }
$$

The TDI is the Tolerable Daily Intake (TDI) for children, because in addition to ingesting elements from toys, children will also ingest elements from food, water and other channels [9]. $10 \%$ is a safety factor, which is usually used to calculate compound limits and evaluate the tolerable concentration of elements in drinking water, and WHO also uses a method of multiplying by a safety factor of $10 \%$ when calculating the tolerable concentration of elements in drinking water [10].

2) Limit setting principle

The TDI of boron element is $0.16 / \mathrm{mg} / \mathrm{kg} / \mathrm{day}$, the age of children is $3-6$ years old, the average weight is $17.6 \mathrm{~kg}$, and the daily exposure dose of class II liquid or viscous material is $400 \mathrm{mg} / \mathrm{day}$ [7]. The above data are brought into the above formula to obtain the limit of boron element:

$$
10 \% \times 0.16 \mathrm{mg} / \mathrm{kg} \times 17.6 \mathrm{~kg} / 0.4 \mathrm{~g}=0.704 \mathrm{mg} / \mathrm{g}=704 \mathrm{mg} / \mathrm{kg}
$$

When the children are $7-12$ years old and the average weight is $31.7 \mathrm{~kg}$, the limit of boron is:

$$
10 \% \times 0.16 \mathrm{mg} / \mathrm{kg} \times 31.7 \mathrm{~kg} / 0.4 \mathrm{~g}=1.268 \mathrm{mg} / \mathrm{g}=1268 \mathrm{mg} / \mathrm{kg}
$$

It should be noted that the EU sets the appropriate age of toys made of viscous materials such as Slime (i.e. "class II materials") under the age of 3, and the average weight of children is $7.5 \mathrm{~kg}$. Therefore, the limit of boron in EN71-3 is $300 \mathrm{mg} / \mathrm{kg}$ [7]. However, considering the production process of Slime at home and abroad, the boron element in Slime comes from borax, which is currently one of the indispensable raw materials in Slime products. With the limit of $300 \mathrm{mg} / \mathrm{kg}$, it is difficult for most Slime products to be formed or the products may fail to be played, thus adding headwinds to China's enterprises.

The scope of application of China's toy standard GB 6675.4-2014 Safety of Toys - Part 4: Migration of Specific Elements includes: palpable liquid, paste and gel (e.g. liquid paint, styling compound), regardless of age or recommended age mark. Therefore, in order to combine with China's national conditions, the following limit model can be adopted for risk assessment.

Migration of boron in Slime for 3- to 6-year-old children tested less than $704 \mathrm{mg} / \mathrm{kg}$ can be seen as allowable risk. Migration of boron in Slime for 7- to 12- year- old children tested less than $1268 \mathrm{mg} / \mathrm{kg}$ can be seen as allowable risk (see Table 2 for details).

\section{CONCLUSION}

EU recalled (detained) toys products of China for 236 times because of chemical security, mainly including: overproof phthalate, and other organic poisonous substances like boron, plumbum, cadmium, and so on. Considering the affordability of the industry, it is suggested to limit the boron element in Silme that is not included in China's toy standards: The limit of migration of boron in 3- to 6-year-old Slime toys shall be less than $704 \mathrm{mg} / \mathrm{kg}$, and the limitation of migration of boron in 7- to 12-year-old Slime toys shall be less than $1268 \mathrm{mg} / \mathrm{kg}$.

\section{ACKNOWLEDGEMENTS}

The authors are grateful to the support of research projects of general administration of customs of China (No. 2020HK104). 


\section{CONFLICTS OF INTEREST}

The authors declare no conflicts of interest regarding the publication of this paper.

\section{REFERENCES}

1. General Administration of Customs of China (2021) Customs Statistical Data Query Platforms. http://43.248.49.97/

2. European Commission (2021) Safety Gate. https://ec.europa.eu/safety-gate-alerts/screen/webReport

3. Chang, Y.J., Chao, H.C., Kong, M.S. and Lai, M.W. (2004) Clinical Analysis of Disc Battery Ingestion in Children. Chang Gung Medical Journal, 27, 673-677.

4. Wang, L., Liu, F., Shao, W., Cui, S., Zhao, Y., Zhou, Y. and He, J. (2019) Graphite Oxide Dopping Polyimide Nanofiber Membrane via Electrospinning for High Performance Lithium-Ion Batteries. Composites Communications, 16, 150-157. https://doi.org/10.1016/j.coco.2019.09.004

5. Cowan, D., Ho, B., Sykes, K.J. and Wei, J.L. (2013) Pediatric Oral Burns: A Ten-Year Review of Patient Characteristics, Etiologies and Treatment Outcomes. International Journal of Pediatric Otorhinolaryngology, 77, 1325-1328. https://doi.org/10.1016/j.ijporl.2013.05.026

6. Hussain, F.A.K. (2009) Evaluating Frozen Beef and Meat Packaging Material Exposed to Low Levels of Ammonia Gas. Doctoral Dissertation, Kansas State University, Manhattan.

7. Van Engelen, J.G.M., van der Zee Park, M., Janssen, P.J.C.M., Oomen, A.G., Brandon, E.F.A., Bouma, K., et al. (2009) Chemicals in Toys. A General Methodology for Assessment of Chemical Safety of Toys with a Focus on Elements. RIVM Rapport 320003001.

8. Duan, X. (2015) Highlights of the Chinese Exposure Factors Handbook. Academic Press, Beijing.

9. Renwick, A.G. (1998) Toxicokinetics in Infants and Children in Relation to the ADI and TDI. Food Additives \& Contaminants, 15, 17-35. https://doi.org/10.1080/02652039809374612

10. Stauber, C. and Casanova, L. (2015) Drinking Water Contamination. In: Routledge Handbook of Water and Health. Routledge, London, 162-168. 